Rev.MVZ Córdoba 20(1):4393-4395, 2015. ISSN: 0122-0268

\title{
EDITORIAL
}

\section{Chikungunya: few months after the attack}

\author{
Chikungunya: unos meses después del ataque
}

En mayo del 2014 se anunció en el editorial de la Rev.MVZ Córdoba la advertencia de la inevitable llegada del virus de chikungunya a Colombia y especialmente en el Caribe por sus condiciones climáticas del trópico húmedo, así como con la presencia del conocido vector competente del dengue: Aedes aegypti (1). La abundante población de este mosquito en el Caribe permitió una adaptación rápida del virus chikungunya y facilitó su diseminación en toda la costa Atlántica. La OPS y el Ministerio de Salud de Colombia conocían de su inminente llegada y destinaron recursos para controlar el vector y mitigar el impacto epidemiológico de este nuevo arbovirus. Sin embargo, se ha observado que las campañas de fumigación no fueron sistemáticas e incluso en algunas poblaciones rurales de la costa Atlántica no se realizaron.

Desde el punto de vista filogenético, el virus de chikungunya que entró a Colombia, es la misma cepa de las islas vírgenes y Saint Martin (datos no publicados) en diciembre del 2013 y confirma los hallazgos de Lancioti y Valadere (2). Con relación a la presentación clínica de la enfermedad, esta ha sido la esperada, con algunas diferencias a las observadas en África y Asia. Aquí en el Caribe colombiano se han presentado pocas mialgias, diarreas, conjuntivitis $y$ manifestaciones hemorrágicas; la artritis y la fiebre siguen siendo patognomónicas. No obstante, se han observado manifestaciones neurológicas como encefalitis y síndrome de Guillan Barré en algunos pacientes (datos no publicados). Al parecer existen casos de hepatitis que podrían estar asociados a la infección viral por CHikungunya con elevación de las enzimas hepáticas, casuística que está reportada en la literatura $(3,4)$.
In May of 2014, the editorial of the MVZ Cordoba magazine announced the warning of the inevitable arrival of the Chikungunya virus to Colombia, especially in the Caribbean region given its climatic conditions of tropical humidity, as well as the presence of the well known competent vector of dengue: Aedes aegypti (1). The abundant population of this mosquito in the Caribbean allowed a quick adaptation of the Chikungunya virus and facilitated its dissemination throughout the entire Atlantic coast. The OPS (PanAmerican Health Organization) and the Ministry of Health of Colombia knew of its imminent arrival and allocated resources to control the vector and mitigate the epidemiologic impact of this new arbovirus. However, it has been observed that the fumigation campaigns were not systematic and did not even take place in some rural populations of the Atlantic coast.

From the phylogenetic point of view, the Chikungunya virus that entered Colombia, is the same strain of that of the Virgin Islands and Saint Martin (unpublished data) in December of 2013 and confirms the findings of Lancioti and Valadere (2). With relation to the clinical presentation of the disease, this has been as expected, with some differences to the ones observed in Africa and Asia. Here in the Colombian Caribbean there have been few cases of myalgia, diarrhea, conjunctivitis and hemorrhagic manifestations; the arthritis and fever are still pathognomonic. Nevertheless, neurologic manifestations such as encephalitis and Guillan Barr'e syndrome in some patients (data not published). It seems that there are some cases of hepatitis that could be linked to the viral infection by Chikungunya with elevation of the hepatic enzymes, casuistic which has been reported in literature $(3,4)$. 
Estas observaciones requieren por parte de las autoridades sanitarias una vigilancia más estricta de los casos postchikungunya. No se sabe tampoco cómo es la coinfección con el dengue y si su asociación con el chikungunya lo hace mas letal o puede formar inmuncomplejos que aceleren o modifiquen su presentación clínica. Se han presentado casos letales asociados a chikungunya pero no se tiene certeza que sea la causa del deceso o si existe una coinfección con otro virus como el dengue (5).

De otra parte, tampoco se han cuantificado los días laborales y escolares perdidos por la enfermedad; el impacto económico de esta patología sin duda es mayor que la gripa estacional y el mismo dengue. Se han registrado incapacidades en el área de la costa Atlántica de hasta 7 días, las artralgias con o sin edema en algunos pacientes persisten por meses al parecer en adultos mayores (datos no publicados).

El Ministerio de Salud frecuentemente señala en los medios de comunicación que la carga de la enfermedad ha sido menor a la esperada, con solo 57.000 casos (6). Sin embargo, se ha observado que gran parte de la población de los departamentos del Caribe no está acudiendo a los hospitales ni a los centros de salud, porque al ellos observar la triada clínica: extantema-fiebre-artralgia, se automedican con acetaminofén. Quizás esa es la aparente razón de la baja casuística y probablemente por eso también hay escases del fármaco.

Finalmente, la percepción de la población sobre la enfermedad es curiosa y a su vez interesante. Algunos creen que es el mosquito y no el virus el agente etiológico de la patología, otros consideran que se transmite de persona a persona por que han observado familiares que enferman en su misma casa. Otros han asociado mortalidad al ingerir alcohol post-infección chikungunya, ya que han coincidido con casos de personas que han fallecido posterior a una fiebre por chikungunya. Algunos mencionan conocer casos en donde la enfermedad ha repetido, situación que ha sido descrita en la literatura (7).
These observations require stricter postChikungunya surveillance from the sanitary authorities. It is also not known how coinfection with dengue is and if its association with Chikungunya makes it more lethal or can form immunocomplex that accelerate or modify its clinical presence. Some lethal cases associated with Chikungunya have been observed, but there is no certainty whether it is the cause of decease or if there is co-infection with another virus such as dengue (5).

On the other hand, there has been no quantification of labor and school days lost due to the disease; the economic impact of this pathology is undoubtedly greater that seasonal colds and even dengue itself. Leaves of up to 7 days have been recorded in the Atlantic coast area, arthralgia with or without edema in some patients seem to persist for months in older adults (data not published).

The Ministry of Health frequently points out in the media that the impact of the disease has been lower than expected, with only 57.000 cases (6). However, it has been observed that great part of the population of the states of the Caribbean region are not heading to the hospitals or health centers, because by observing the clinical triage: exanthema -fever-arthralgia, they are selfmedicating with acetaminophen. Maybe that is the apparent reason for the low casuistic and probably also the reason for lack of the medication.

Finally, the perception of the population regarding the disease is curious and interesting at the same time. Some believe that it is the mosquito and not the virus of the etiological agent of the pathology, others consider it to be contagious because they have observed members of the same household get sick. Other have associated mortality to ingestion of alcohol postchikungunya infection, given the coincidence of cases where a person has died after a fever due to Chikungunya. Some mention to know of cases where the disease has repeated itself, situation which has been described in literature (7). 
Poco sabemos en Colombia de este nuevo arbovirus y se requiere analizar su genoma para observar si existen mutaciones y asociarlas con más profundidad con la presentación clínica que se está dando en los pacientes. Se necesita que se establezca si la coinfección con otros arbovirus exacerba o no los síntomas. Sería importante considerar una vacuna con cepas autóctonas.
Little is known in Colombia of this new arbovirus and its genomes must be analyzed to observe if there are mutations and associate them more in depth with the clinical presentation that is presenting itself in patients. There is a need to establish whether the co-infection with other arbovirus exacerbates the symptoms or not. It would be important to consider a vaccine with autochthonous strains.

\section{REFERENCIAS}

1. Gonzalez M, Mattar S. Virus Chikungunya in Colombia, a simple matter of time? Rev MVZ Córdoba 2014; 19:4045-4046.

2. Lanciotti R, Valadere AM. Transcontinental movement of asian genotype Chikungunya Virus. Emerg Infect Dis 2014; 20:14001403.

3. Economopoulou $A^{1}$, Dominguez $M$, Helynck B, Sissoko D, Wichmann O, Quenel P, et al. Atypical Chikungunya virus infections: clinical manifestations, mortality and risk factors for severe disease during the 2005-2006 outbreak on Réunion. Epidemiol Infect 2009; 137(4):534-41. doi: $10.1017 /$ S0950268808001167.

4. Mohan $\mathrm{A}^{1}$, Kiran $\mathrm{DH}$, Manohar IC, Kumar DP. Epidemiology, clinical manifestations, and diagnosis of Chikungunya fever: lessons learned from the re-emerging epidemic. Indian J Dermatol 2010; 55(1):54-63. DOI: 10.4103/0019-5154.60355.
5. Omarjee R, Prat CM, Flusin O, Boucau S, Tenebray $B$, Merle $O$, et al. Importance of case definition to monitor ongoing outbreak of chikungunya virus on a background of actively circulating dengue virus, St Martin, December 2013 to January 2014. Euro Surveill. 2014; 19(13): pii=20753. URL Available in: http://www.eurosurveillance. org/images/dynamic/EE/V19N13/art20753. pdf

6. Instituto Nacional de Salud. Chikunguña a semana 49. INS; 2014. URL Disponible en: http://www.ins.gov.co/ Noticias/Chikungunya/Resumen $\% 20$ Chikungu\%C3\%B1a\%20SEMANA\%2049. pdf

7. Powers A, Logue C. Changing patterns of chikungunya virus: re-emergence of a zoonotic arbovirus. J Gen Virol 2007; 88:2363-2377.

\section{Salim Mattar V. Ph.D. Marco González T. M.Sc.}

